\title{
Tribally Controlled Community College Libraries: A Paradigm for Survival
}

\section{Lotsee Patterson and Rhonda Harris Taylor}

This study reports on the results of a mail survey instrument administered to tribally controlled college libraries during 1993, just before the colleges were granted federal land-grant college status. Data obtained from sixteen respondents, representing 66.66 percent of the twenty-four tribally controlled colleges, provided a baseline profile of the fundamental characteristics of tribally controlled college libraries. The report focuses on the data most comparable to nontribal college libraries: budget, personnel, service population, advisory committees, collections, facilities, services, networking, and computer utilization. The portrait that emerged is of small academic libraries. However, these libraries also reflect the broad-based missions of their parent institutions, combining academic library functions with public library services and elements of tribal culture. Driven by unmet educational needs and the will to retain and strengthen tribal heritages and to support traditional values, these college libraries represent a paradigm for survival.

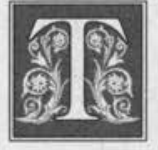

he evolution and growth of tribally controlled community colleges represent one of the most remarkable developments in American higher education during the latter half of this century. These colleges, numbering twenty-four at the time of this study, are geographically clustered in thirteen states, with fifteen of the colleges located in Montana, North Dakota, and South Dakota. Table 1 illustrates the geographic dispersal of the other nine colleges. Collectively, tribal colleges enrolled more than 16,000 students in $1994 .^{1}$
The paradigm that institutions of higher education traditionally share has been redefined in tribal colleges. Although there are many similarities between tribal colleges and those owned and operated by a state government, there also are a number of striking differences. Perhaps the most obvious differences are the tribal institutions' philosophies, missions, goals, and objectives, which reveal a mixture of the usual academic programmatic statements combined with an articulation of the necessity to promote preservation of traditional tribal culture. Driven by unmet educational needs and

Lotsee Patterson is an Associate Professor and Rhonda Harris Taylor is an Assistant Professor at the School of Library and Information Studies, University of Oklahoma; e-mail: Ipatterson@uoknor.edu and rtaylor@uoknor.edu. 


\section{TABLE 1 \\ List of Tribally Controlled Colleges in the United States with Date of Charter and Name of Chartering Entity, 1994*}

\begin{tabular}{|c|c|c|}
\hline Tribally Controlled College & Charter Date & Chartered By \\
\hline Bay Mills Comm. College, MI & 1984 & Bay Mills Tribe \\
\hline Blackfeet Comm. College, MT & 1974 & Blackfeet Tribal Business Council \\
\hline Cheyenne River Comm. College, SD & 1973 & $\begin{array}{l}\text { Cheynne River Sioux Tribe } \\
\text { (1st charter) }\end{array}$ \\
\hline College of the Menominee Nation, WI & 1993 & Menominee Nation \\
\hline D-Q University, CA & 1971 & [Indian-controlled] \\
\hline Dull Knife Memorial College, MT & 1975 & Northern Cheyenne Tribal Council \\
\hline Fond du Lac Comm. College, MN & 1987 & Fond Du Lac Reservation \\
\hline Fort Belknap College, MT & 1984 & Fort Belknap CommunityCouncil \\
\hline Fort Berthold Comm. College, ND & 1973 & $\begin{array}{l}\text { Three Affiliated Tribes of the } \\
\text { Fort Berthold Reservation }\end{array}$ \\
\hline Fort Peck Comm. College, MT & 1978 & $\begin{array}{l}\text { Fort Peck Assiniboine and Sioux } \\
\text { Tribes (Tribal Executive Board) }\end{array}$ \\
\hline Lac Courte Oreilles Ojibwa College, WI & 1982 & Lac Courte Oreilles \\
\hline Leech Lake Comm. College, MN & 1993 & \\
\hline Little Big Horn College, MT & 1980 & \\
\hline Little Hoop Comm. College, ND & 1974 & Devils Lake Sioux Tribe \\
\hline Navajo Comm. College, AZ & 1968 & Navajo Nation \\
\hline Nebraska Indian Comm. College, NE & 1979 & $\begin{array}{l}\text { Omaha, Santee Sioux, and } \\
\text { Winnebago Tribes of Nebraska }\end{array}$ \\
\hline $\begin{array}{l}\text { Northwest Indian College, WA } \\
\text { (formerly Lummi Comm. College) }\end{array}$ & 1983 & Lummi Indian Business Council \\
\hline Oglala Lakota College, SD & 1971 & Oglala Sioux Tribe \\
\hline Salish Kootenai College, MT & 1976 & $\begin{array}{l}\text { Confederated Salish and Kootenai } \\
\text { Tribes }\end{array}$ \\
\hline Sinte Gleska, SD & 1971 & Rosebud Sioux Tribe \\
\hline Sissteon Wahpeton Comm. College, SD & 1979 & $\begin{array}{l}\text { Tribal Council of the Sissteon } \\
\text { Wahpeton Sioux Tribe }\end{array}$ \\
\hline Standing Rock College, ND & 1973 & Standing Rock Sioux Tribal Council \\
\hline Stone Child College, MT & 1984 & Chippewa-Cree Business Committee \\
\hline Turtle Mountain Comm. College, ND & 1972 & Turtle Mountain Chippewa Tribe \\
\hline \multicolumn{3}{|c|}{$\begin{array}{l}\text { *Sources: American Indian Higher Education Consortium and current catalogs of individual } \\
\text { colleges. } \\
\text { Omitted from this table: Three vocational technical colleges (Crownpoint Institute of Technol- } \\
\text { ogy, Southwest Polytechnic Institute, United Tribes Technical College), Haskell Indian Nations } \\
\text { University (Bureau of Indian Affairs postsecondary institution), and the Southwestern Indian } \\
\text { Polytechnic Institute. }\end{array}$} \\
\hline
\end{tabular}

the need to maintain tribal traditions, these colleges exemplify, for their respective tribes, a paradigm for survival.

Most of the tribally controlled colleges havie followed a pattern of development not unlike many state institutions. They began as two-year colleges and, over time, some progressed to four-year institutions. Several of them now offer a limited number of graduate programs. Al- most all have gained, or are candidates for, regional accreditation, the majority of them with the North Central Association of Colleges and Schools. They are expected to make significant strides forward with the recent congressional action giving them land-grant status. ${ }^{2}$

The relationship of the libraries within these colleges to the overall educational mission presented a management sce- 
nario worthy of investigation. The harsh realities imposed upon the operation of these libraries, situated in sparsely settled areas with extremely limited funding and faced with institutional mandates to help fulfill the special needs of the tribes they serve, raised interesting questions about tribal college library services, collections, facilities, budgets, and staffs.

This study was undertaken to compile a baseline profile of the fundamental characteristics of tribally controlled college libraries. The resulting report also explores the relationship of college library operations to the parent institutions' missions, goals, and objectives.

\section{Historical Development}

Because community colleges are products of the twentieth century, tribally controlled colleges are a manifestation of the late twentieth century. Pursuant to the Navajo Community College Act, the $\mathrm{Na}$ vajo tribe chartered the first tribally controlled community college in $1968 .^{3}$ Oth-

\section{Third was the desire to strengthen the tribe through academic learning, vocational training, and cultural preservation.}

ers quickly followed: Sinte Gleska College in South Dakota, D-Q University in California, and Oglala Lakota College in South Dakota, in 1971; and Turtle Mountain College in North Dakota, in 1972. These are representative of a flurry of tribally controlled colleges established in the 1970s and 1980s. Most owe their existence to the Tribally Controlled Community College Assistance Act, passed by Congress in 1978, which provides annual appropriations based on the number of fulltime students attending the college. ${ }^{4}$ These funds are nominal contributions to the total operating budgets. Tuition and grants from government and private sources provide the rest of the revenue for what are always tight budgets.
Statements obtained from the colleges' catalogs reveal a uniqueness of purpose articulated in their missions, goals, and objectives. For example, Bay Mills Community College, Michigan's only tribally controlled college, includes as one of its objectives: "To foster a spirit of pride in Native American language, culture and history through participation in classes and cultural activities." ${ }^{5}$ The mission statement of Fort Belknap College, located in north central Montana, reads in part: "The College will strive to provide opportunities for individual self-improvement for survival in a rapidly changing technological world and maintain the cultural integrity of the Assiniboine and Gros Ventre Tribes." ${ }^{1}$ The philosophy of Fort Berthold Community College in North Dakota is representative of the cultural sensitivity reflected in almost all of the tribal colleges' mission statements: "The philosophy of the Fort Berthold Community College emphasizes the interweaving of tribally distinctive cultural elements into the post-secondary process."7 These statements articulate the reasons why tribal colleges were formed.

The results of a study conducted by James F. Hill, in which he examined the history of the establishment of tribal colleges, found that: "The colleges began in response to the conditions experienced at off-reservation institutions." ${ }^{18}$ Sinte Gleska University President Lionel R. Bordeaux addressed some of these challenges. They centered on financial-aid limitations, cultural isolation, and family considerations. Second was the need for a local forum to discuss community and tribal issues, and third was the desire to strengthen the tribe through academic learning, vocational training, and cultural preservation. ${ }^{9}$

Almost all the colleges are commuter campuses. Main campuses lack residential halls, but many of them offer other amenities such as food service. Several provide a college-sponsored transportation system and child care. ${ }^{10}$ The average 
student is thirty-one years old, is Native American, and comes from a home whose average income is far below the national average. ${ }^{11}$

Two organizations have been established to support the tribal colleges: the American Indian Higher Education Consortium (AIHEC) and the American Indian College Fund (AICF). AIHEC was founded in 1972 by six tribally controlled community colleges with a view toward mobilizing a concerted effort to address the developmental problems common to them all. Today, it is a cooperatively sponsored effort on the part of thirty-one member institutions to provide a direct mechanism for facilitating access to resources needed for their continued development. ${ }^{12}$ The AICF, launched in 1989 , models the United Negro College Fund and has yet to fulfill its potential as an important source of financial support for tribal colleges.

Tribal colleges represent a relatively new presence in American higher education. This report provides preliminary data gathered on the tribal college libraries and suggests directions for further inquiry.

\section{Terminology}

No study involving Native Americans can be presented without first clarifying terms. Some terms used throughout this report are described and defined below.

Indian tribe means an Indian tribe, band, nation, or other organized group or community, including a Native Village, Regional Corporation, or Village Corporation (as those terms are defined in the Alaska Native Claims Settlement Act), which is recognized as eligible for the special programs and services provided by the United States to Indians because of their status as Indians. ${ }^{13}$

Tribally controlled colleges refers to those institutions that are administered and operated by a federally recognized Indian tribe. In 1994, the U.S. Senate's Committee on Indian Affairs identified twenty- four tribally controlled community colleges and also listed two tribally controlled vocational colleges, two Bureau of Indian Affairs postsecondary institutions, and the Institute of American Indian Arts (IAIA). ${ }^{14}$ For purposes of this study, the authors considered only the twenty-four

Most of the colleges are located in the Western states where access to an accredited library school is extremely difficult.

institutions listed in table 1 (omitting three technical-vocational colleges, one Bureau of Indian Affairs postsecondary institution, and the specialized IAIA).

Land-grant colleges are those colleges established for the benefit of agriculture and the mechanic arts in accordance with the provisions of the Act of July 2, 1862, as amended in 12 Stat.503; 7 U.S.C. 301-305, 307 , and $308 .^{15}$

\section{Tribal College Libraries}

Undertaking a study of libraries in tribally controlled colleges is not an easy task, as they are often overlooked in the literature addressing academic librarianship. Even obtaining their names and addresses requires research. In fact, the many articles, reports, and studies on tribal colleges seldom mention the libraries. Also, Indian people and Native American institutions have been subjected to so many studies that there is a reluctance to be part of another one.

It is assumed that many of the challenges endemic to tribal colleges are also ones affecting tribal college libraries and their management. Critical factors include recruiting and retaining staff from a limited pool of qualified personnel. Most of the colleges are located in the Western states where access to an accredited library school is extremely difficult. It would not be surprising, then, to find that only a few tribal librarians possess a graduate degree in library and informa- 


\begin{tabular}{|c|c|}
\hline \multicolumn{2}{|c|}{$\begin{array}{l}\text { TABLE } 2 \\
\text { Total Annual Budgets of Responding } \\
\text { Libraries, with Estimated Percentage } \\
\text { of Funding Received from LCSA Title IV, } \\
\text { Special Grants, or Basic Grants* }\end{array}$} \\
\hline $\begin{array}{l}\text { Total Annual } \\
\text { Budgets in } \\
\text { Ascending Rank } \\
\text { Order** }\end{array}$ & $\begin{array}{l}\text { Estimated \% Funding } \\
\text { from LSCA Title IV, } \\
\text { Special Grants, } \\
\text { or Basic Grants }\end{array}$ \\
\hline $\begin{array}{l}\$ 4,000 \\
\$ 10,000 \\
\$ 10,000 \\
\$ 10,000 \\
\$ 40,000 \\
\$ 42,400 \\
\$ 45,500 \\
\$ 50,000 * * * \\
\$ 60,000 * * * \\
\$ 65,000 \\
\$ 106,200 \\
\$ 135,500 \\
\$ 172,300 \\
\$ 175,000\end{array}$ & $\begin{array}{l}100 \% \\
50 \% \\
\text { none indicated } \\
\text { none indicated } \\
10 \% \\
9 \% \\
\text { none indicated } \\
\text { none indicated } \\
80 \% \\
\text { none indicated } \\
\text { none indicated } \\
\text { none indicated } \\
2 \% \\
0.5 \%\end{array}$ \\
\hline \multicolumn{2}{|c|}{$\begin{array}{l}\text { *Two respondents did not answer this question. } \\
\text { **Rounded to nearest } \$ 100 \text {. } \\
\text { ***Figure is the low end of a range provided by } \\
\text { respondent. }\end{array}$} \\
\hline
\end{tabular}

community-based information needs is often woefully lacking for these young libraries. In some instances, LSCA (Library Services and Construction Act) funds have been used to supplement college budget appropriations to the libraries.

A number of the tribal college libraries function as both academic library and public library for their reservations. This strategy, though reasonable, places additional burdens not only on budgets, but also on staff and collections.

The diversity of services provided, the unique status of the parent institutions of these libraries, and the general lack of information about them in the professional literature prompted this study. The authors wanted to determine the present status of tribal college libraries and to identify some of their unique characteristics.

The timing of this study was significant because land-grant status was granted to tribally controlled colleges by the federal government in 1994. This status is expected to bring changes for the tribal colleges, tion studies. Low salaries and isolation from other library professionals would be expected to contribute to a high turnover rate of library employees.

Inadequate facilities are another challenge confronting tribal colleges and their libraries. Some tribal libraries can be found in quarters such as old tribal gymnasiums and temporary buildings; others are housed in new, beautifully designed spaces.

Tribal college libraries share the necessity of overcoming budgetary constraints with nontribal college libraries. Money to purchase library materials to support both the curricula and all the other especially if funding for which the colleges are now eligible is actually appropriated.

\begin{tabular}{|c|c|c|}
\hline \multicolumn{3}{|c|}{$\begin{array}{l}\text { TABLE 3 } \\
\text { Terminal Degrees Held by Library Directors } \\
\text { and Library Directors Identified As Native* }\end{array}$} \\
\hline $\begin{array}{l}\text { Terminal Degree } \\
\text { Held By } \\
\text { Library Dir. }\end{array}$ & $\begin{array}{l}\text { No. of Dirs. } \\
\text { Holding This } \\
\text { Degree }\end{array}$ & $\begin{array}{l}\text { No. of Native } \\
\text { Dirs. Holding } \\
\text { This Degree }\end{array}$ \\
\hline $\begin{array}{l}\text { No degree indicated } \\
\text { (has college-level work) }\end{array}$ & 1 & 1 \\
\hline Bachelor's degree & 3 & 1 \\
\hline $\begin{array}{l}\text { Bachelor's degree with } \\
\text { additional hours } \\
\text { Master's degree } \\
\text { Doctorate }\end{array}$ & $\begin{array}{l}1 \\
9 \\
1\end{array}$ & $\begin{array}{l}0 \\
1 \\
0\end{array}$ \\
\hline
\end{tabular}




\section{Methodology}

The authors attempted to gather baseline data on the libraries of the tribally controlled colleges by mailing a survey questionnaire, accompanied by a cover letter, in 1993. They also requested and obtained current college catalogs from the institutions.

\section{Data Collection and Analysis}

Sixteen responses were eventually received, representing 66.66 percent of the twenty-four tribally controlled colleges (see table 1). This report focuses on the data most comparable to nontribal college libraries: budget, personnel, service population, advisory committees, collections, facilities, services, networking, and computer utilization.

\section{Budget}

In response to a query requesting a figure for the "library's total annual budget," fourteen of the sixteen respondents provided a total dollar amount, as indicated in table 2 (budgets have been rounded to the nearest $\$ 100$ ). As table 2 shows, the fourteen libraries responding to this question reported total budgets ranging from $\$ 4,000$ per year to $\$ 175,000$, with a mean of $\$ 66,135$. Of the fourteen respondents replying to a checklist of funding sources, seven (50\%) identified federal LSCA monies, whether special grants or basic grants, as one source of funding for the library (also shown in table 2).

\section{Personnel}

Data provided by respondents helped to profile the personnel staffing of tribally controlled college libraries. Table 3 lists terminal degrees held by the directors of these libraries at the time of the study (1993). Fifteen of the sixteen respondents completed the question about the educational attainment level of the library director. Ten $(66.66 \%)$ of the fifteen responding libraries completing this question had directors with master's or doctorate de-

\begin{tabular}{|cc|}
\hline $\begin{array}{c}\text { TABLE 4 } \\
\text { Number of Paid Full-Time } \\
\text { and Part-Time Library Staff } \\
\text { Members Identified As Native }\end{array}$ \\
\hline \hline \begin{tabular}{ll} 
No. of Paid Full- & No. of Paid Full- \\
and Part-Time & and Part-Time \\
Library Staff & Library Staff \\
Including Director* & Identified As Native \\
\hline 1 & 0 \\
1 & 0 \\
1 & 0 \\
1 & 0 \\
1 & 0 \\
1 & 1 \\
2 & 1 \\
2 & 1 \\
2 & 2 \\
3 & 2 \\
3 & 2 \\
4 & 3 \\
4 & 4 \\
5 & 4 \\
6 & $*$ \\
8 & 7 \\
\hline *Respondent did not provide this \\
information.
\end{tabular} \\
**Ranked in ascending order. \\
\hline
\end{tabular}

grees. However, of these fifteen responding libraries, only three $(20 \%)$ of the library directors of the libraries responding to a question about ethnicity were identified as being Native American. Respondents identified all three of those Native directors as being members of the tribe controlling the college. Out of the ten library directors identified as holding a master's degree or doctorate, only one ( $10 \%$ of this group holding graduate degrees) was identified as being Native American. Also, it should be noted that respondents were not asked to identify the graduate degrees held by library directors as being in library/information studies, so it is possible that the graduate degrees were in other discipline areas. Also worthy of note is the fact that for the sixteen responding libraries, twelve 


\begin{tabular}{|c|c|}
\hline \multicolumn{2}{|c|}{$\begin{array}{c}\text { TABLE } 5 \\
\text { Use of Library Boards and Library } \\
\text { Committees By Responding Libraries* }\end{array}$} \\
\hline $\begin{array}{l}\text { Type of Library } \\
\text { Board/Committee }\end{array}$ & $\begin{array}{l}\text { Number of Libraries } \\
\text { Reporting Use }\end{array}$ \\
\hline Use of Library Board & 4 \\
\hline $\begin{array}{l}\text { Use of Library Committee } \\
\text { Use of Both Library }\end{array}$ & 6 \\
\hline Committee and Library Boa & ard \\
\hline Use of College Board & 1 \\
\hline
\end{tabular}

*Four respondents did not answer this question.

(75\%) of the directors were female and four $(25 \%)$ were male.

Table 4 helps to profile the larger picture of overall staffing for the tribal libraries. For the sixteen responding libraries, the number of paid staff positions (combining full-time and part-time staff members and including the directors) for those libraries ranged from one to eight, for a mean of 2.81 positions. Only three $(18.75 \%)$ of the sixteen responding libraries reported using volunteers.

As shown in table 4, fifteen of the sixteen responding libraries identified

\begin{tabular}{|cc|}
\hline \multicolumn{2}{|c|}{$\begin{array}{c}\text { TABLE } 6 \\
\text { Percentage of Service Population } \\
\text { Identified As Tribal Members* }\end{array}$} \\
\hline \hline \% of Service Pop- & $\begin{array}{l}\text { No. of Libraries } \\
\text { Reporting This \% } \\
\text { As Tribal Members** }\end{array}$ \\
\hline $45 \%$ & 1 \\
60 & 1 \\
80 & 2 \\
85 & 2 \\
86 & 1 \\
90 & 2 \\
95 & 2 \\
97 & 1 \\
98 & 1 \\
\hline *Three respondents did not answer this question. \\
**In ascending rank order.
\end{tabular}

whether paid full- and parttime staff members were Native American. The thirty-nine full- and part-time positions reported by those fifteen libraries included twenty-seven $(69.23 \%)$ that were held by Native Americans. This percentage is in contrast to the earlier percentage of library directors $(20 \%)$ identified as Native American.

\section{Advisory Committees}

Typically, college libraries have advisory committees, usually composed of faculty and student members. Responses in this study reflected a similar pattern.

As seen in table 5, of the sixteen respondents in this study, twelve answered the survey question about use of library boards/committees. Four respondents indicated that the tribal college library used a library board, six indicated use of a library committee, and one indicated use of both. One response indicated use of a college board, presumably in lieu of a library board/committee. It should be noted that respondents were not asked to describe the membership of these boards/committees.

\section{Service Population}

Of the sixteen returned survey questionnaires, thirteen answered the question about ethnicity of the population served by the library (see table 6). Eleven $(84.61 \%)$ of the thirteen libraries answering this question indicated that at least 80 percent of their service populations were tribal members. Two of the thirteen libraries answering this question profiled service populations of tribal members at 45 and 60 percent.

It is worth noting that in addition to tribal members being served by these libraries, eleven of the thirteen responding libraries answering the 
question about the ethnicity of their service populations identified Native American nontribal members. In addition to tribal members being served by these libraries, percentages of Native American nontribal members being served by these eleven libraries ranged from one to 13 percent, with a mean of five percent.

\section{Collections}

Table 7 illustrates the estimated size of collections held by the tribally controlled college libraries in this study. It shows estimates for the number of print volumes, nonprint items, and periodical titles held by the sixteen responding libraries. Table 7 also displays a range of 4,000 to 46,000 volumes for print collections of these libraries, with a mode of 8,000 volumes and a mean of 14,500 volumes. The estimated number of nonprint titles held by the sixteen responding libraries ranged from 100 to 2,000 titles, with a mean of 521.88 titles. The estimated number of periodical titles held by the sixteen responding libraries ranged from 48 to 750 titles,

\section{TABLE 8}

\section{Sources of Acquisitions for Responding Libraries}

Source of Acquisitions*

No. of Libraries

Reporting Use of This Source

\begin{tabular}{lr}
\hline Purchased directly from publishers & 13 \\
Purchased from vendors & 15 \\
Purchased from bookstores & 8 \\
Gifts from individuals & 15 \\
Gifts from other libraries & 12 \\
Gifts from publishers & 6 \\
Other &
\end{tabular}

Remainder houses

*More than one source could be indicated by respondents. 1

TABLE 7

Estimated Size of Library Collections of Responding Libraries

with a mean of 153 titles. As expected, 100 percent of the sixteen respondents indicated there was specialized collection development in the areas of Indian and/or tribal materials for these tribal college libraries.

As with other academic libraries, responses from the sixteen returned survey questionnaires indicated that the tribally controlled college libraries were using standard sources of acquisitions to build collections: publishers, vendors, and gifts (see table 8 ). Respondents were allowed to indicate more than one source of acquisitions on the survey questionnaire. Fifteen of the sixteen responding libraries, or 93.75 percent of the respondents, indicated that they used ven- 


\begin{tabular}{|cc|}
\multicolumn{1}{c|}{ TABLE 9 } \\
\multicolumn{1}{c|}{$\begin{array}{c}\text { Organization of Materials Classification } \\
\text { Schemes Used By Responding Libraries }\end{array}$} \\
\hline \hline Classification Schemes & $\begin{array}{l}\text { Number of Libraries } \\
\text { Reporting Use of } \\
\text { This Scheme }\end{array}$ \\
\hline $\begin{array}{l}\text { Dewey Decimal Classification } \\
\text { Library of Congress Classification } \\
\text { Both Dewey Decimal and Library } \\
\text { of Congress Classification }\end{array}$ & 12 \\
\hline
\end{tabular}

square footage estimate for their libraries' facilities. The estimates, as shown in table 10 , ranged from 1,100 to 16,000 square feet, with a mode of 4,000 square feet and a mean of $5,141.81$ square feet.

\section{Services}

Table 11 illustrates the number of hours per

dors for purchasing materials, and the same percentage indicated that they received gifts from individuals. Close to the percentage of respondents using vendors was the percentage of respondents using direct purchase from publishers $(81.25 \%)$ for acquisitions.

The sixteen returned survey questionnaires revealed that all sixteen tribal college library collections were at least partially cataloged and classified (see table 9). Dewey Decimal Classification was the most popular classification scheme, being cited by twelve $(75 \%)$ of the sixteen responding tribal libraries. Use of the $\mathrm{Li}$ brary of Congress Classification Scheme was cited by two $(12.5 \%)$ of the sixteen responding tribal libraries. One tribal library indicated use of both Dewey Decimal and Library of Congress Classification Schemes in order to accommodate a juvenile collection.

\section{Facilities}

Fifteen of the sixteen responding libraries indicated whether they had more than one facility. As seen in table 10 , of the fifteen libraries responding to this question, two (13.33\%) were housed in more than one facility, with one providing nine centers at off-site locations.

Table 10 illustrates the estimated square footage of the library facilities for eleven of the sixteen respondents. These eleven respondents provided a week that the responding libraries were open. The sixteen responding libraries reported being open for a mean of 49.12 hours per week, ranging from a low of 40 hours per week to a high of 69 hours per week. The mode was 42.5 hours per week.

All sixteen responding libraries indicated that they provided interlibrary loan services. In addition, fifteen of the sixteen responding libraries responded in the affirmative to a query about availability of "a copy machine for paper materials (books, magazines)" for library users.

There also was some indication that the

\begin{tabular}{c} 
TABLE 10 \\
$\begin{array}{c}\text { Estimated Size of Facilities } \\
\text { of Responding Libraries* }\end{array}$ \\
\hline \hline
\end{tabular}

Estimated Sq. No. of Libraries Footage of Reporting This

Library Facility** Estimated Sq. Footage

\begin{tabular}{rl}
1,100 & 1 \\
1,500 & 1 \\
1,560 & 1 \\
2,400 & 1 \\
2,500 & 1 \\
4,000 & 2 \\
7,000 & 1 \\
7,500 & 1 \\
9,000 & 1 \\
16,000 & 1 \\
\hline
\end{tabular}

*Five respondents did not answer this question. **Ranked in ascending order. 
service functions performed by these tribal college libraries resembled those of public library services. For instance, out of sixteen respondents, four (25\%) answered in the affirmative to a question about delivery of library materials to patrons. The four indicated that they delivered materials to senior citizens, and three of the four also indicated delivery services to detention centers and to individuals with disabilities.

Table 12 reports the results of a checklist question dealing with the preservation methods, records management, and archival functions being performed by the tribal college libraries. Respondents could indicate more than one function on the survey questionnaire. Of the sixteen respondents, ten $(62.5 \%)$ reported engaging in preservation, records management, and/ or archival functions, with the archival function being performed least often.

\section{Networking}

The authors expected that given the broad-based service missions of the parent institutions, the tribal college libraries would be more likely to provide services usually considered to be in the purview of a public library. Several questions on the survey questionnaire addressed

\section{TABLE 12}

\section{Preservation, Records Management, and Archival Functions Reported by Responding Libraries*}

\begin{tabular}{ll} 
Function** & $\begin{array}{l}\text { Number of Libraries } \\
\text { Reporting This Function }\end{array}$ \\
\hline
\end{tabular}

Preservation Activities
Records Management
Archival Functions
Preservation, Records
Management, and Archival
Functions Not Reported

\section{6}

5

4

Functions Not Reported

* Six respondents did not answer this question.

**More than one function could be indicated by respondents.

\section{TABLE 11}

Weekly Number of Hours Responding Libraries Are Open for Service

\begin{tabular}{lc}
$\begin{array}{l}\text { Weekly No. of } \\
\text { Hours Library } \\
\text { Is Open* }\end{array}$ & $\begin{array}{l}\text { No. of Libraries } \\
\text { Reporting This } \\
\text { No. of Hours }\end{array}$ \\
\hline 40.0 & 3 \\
42.5 & 4 \\
45.0 & 1 \\
48.5 & 1 \\
51.0 & 1 \\
51.5 & 1 \\
56.0 & 1 \\
57.0 & 1 \\
57.5 & 1 \\
60.5 & 1 \\
69.0 & 1 \\
\hline
\end{tabular}

* Ranked in ascending order.

the question of whether these tribal libraries had a relationship with their state library consultants. The survey questionnaire asked responding librarians to name a state library consultant and to indicate the number of contacts within the past six months. Of the sixteen responses received, eight $(50 \%)$ of the respondents named a state library consultant. Four of the eight $(50 \%)$ reported consulting this individual one to five times over the past six months. Two of the eight respondents who named a state library consultant reported having eleven or more contacts over the past six months. Interestingly, two of the sixteen respondents did not name a state library consultant, but did report having contact with one within the past six months.

\section{Computer Resources}

Table 14 shows the tasks performed by library staff 


\begin{tabular}{|ll}
\hline \multicolumn{1}{|c}{$\begin{array}{c}\text { TABLE 13 } \\
\text { Estimated Number of } \\
\text { Contacts with State Library } \\
\text { Consultant Over Last Six Months* }\end{array}$} \\
\hline \hline $\begin{array}{ll}\text { Estimated No. } \\
\text { of Contacts }\end{array}$ & $\begin{array}{l}\text { No. of Libraries } \\
\text { Reporting This } \\
\text { No. of Contacts }\end{array}$ \\
\hline 0 & 2 \\
$1-5$ & 4 \\
11 or more & 2 \\
\hline
\end{tabular}

*As reported by respondents who indicated the name of a consultant.

using the computer resources of the tribal college libraries. More than one task could be indicated on the survey questionnaire by the respondents and all sixteen respondents answered this question. Five $(31.25 \%)$ indicated that they performed circulation functions with computer resources. Four $(25 \%)$ indicated that budgeting and accounting functions were performed using automation, whereas five $(31.25 \%)$ used computer resources for e-mail purposes. However, the highest percentage of responses regarding use of computer resources centered on cataloging and word processing, at 87.50 percent and 75 percent, respectively.

Table 15 illustrates the breakdown of the kinds of computer resources used by library patrons, based on the sixteen respondents' survey answers. The sixteen responses indicated that the computer resources available for patrons were used most frequently for word processing ( $68.75 \%$ of respondents) and for locating books or audiovisual materials in other libraries $(62.50 \%$ of respondents). In contrast to the percentage $(62.50 \%)$ of respondents who indicated that library computer resources were being used by patrons to locate materials in other libraries, only eight $(50 \%)$ of the respondents indicated that computer resources were being used by patrons to locate materials in the college library. The use of computer resources by tribal college library patrons for educational purposes also was indicated, surprisingly, by only four ( $25 \%)$ of the sixteen respondents. A similar percentage of respondents $(31.25 \%)$ indicated that their patrons used library computer resources for computer games. The same percentage of respondents indicating patron use of computer resources for games $(31.25 \%)$ also indicated that their patrons used library computer resources to find periodical articles.

\section{Summary}

Data from this study of tribally controlled college libraries provide insight into the status of the sixteen responding libraries. Significant to this study is the youth of the parent institutions. The oldest tribal college in the United States is not quite thirty years old; thus, the tribal college libraries are in their infancy. The colleges are small, with the largest enrollments hovering around 2,000 FTE (full-time enrollment). ${ }^{16}$

The special emphasis on collecting tribal material, as well as information about Indian tribes in general, was clearly

\begin{tabular}{|cc}
\multicolumn{2}{c}{ TABLE 14 } \\
\multicolumn{2}{|c}{ Tasks Performed by Library Staff Using } \\
Computer Resources of Responding Libraries \\
\hline \hline Task Utilizing & No. of Libraries \\
Computer Resources* & $\begin{array}{l}\text { Reporting Performance } \\
\text { of This Task by Staff }\end{array}$ \\
\hline Circulation & 5 \\
Cataloging & 14 \\
Budgeting/accounting & 4 \\
Word processing & 12 \\
E-mail & 5 \\
\hline
\end{tabular}

*More than one task could be indicated by respondents. 
a pattern in all libraries responding to the survey. Such an emphasis was to be expected of libraries where no less than 45 percent of their user populations are tribal members and the curriculum is infused with tribal cultural elements. Services were perhaps the most at variance with traditional academic libraries. The philosophy of these tribally controlled colleges reflects their integration with, and dedication to the improvement of, the tribal community at large. This inclusiveness extends to library services. Delivering materials directly to off-campus users and providing other public library services, managing tribal records, and serving as archival centers were some of the more common roles performed by the tribal college libraries. However, given the emphasis in college missions on preservation of culture and language, the authors anticipated that archival functions would be performed by a larger percentage of respondents than was indicated by this study. However, the most likely explanation for this lack of involvement with archives could lie in the small number of staff members, or could simply be that no tribal or college archives exist. It might also be attributed to the unavailability of dedicated funding, a need for grantsmanship, a lack of staff training, or other limitations ubiquitous to small academic libraries. It also is possible that archival and records management functions were being performed by other entities within the academic or tribal institutions.

At the time of this study, networking through computers was just beginning to appear in these tribally controlled college libraries, although this is expected to change rapidly given the format of available information resources and the expan- sion of the "information highway." Tribal libraries in Montana, for example, have joined other college libraries in the state and formed a group called Outreach Montana Networked Information (OMNI), which seeks to share networks in order to link databases, college catalogs, and other library resources. ${ }^{17}$

It remains to be seen what overall effect recent technological developments, such as the rapidly expanding use of the Internet, will have on tribal colleges and their library users. Its use and that of CD-

Delivering materials directly to offcampus users and providing other public library services, managing tribal records, and serving as archival centers were some of the more common roles performed by the tribal college libraries.

ROM technology can have a significant impact on sparse print collections by offering access to additional resources both on and off campus.

Given the environments reported in the surveys, it is clear that most of the tribal college libraries will be struggling 
for some time to match the collections, facilities, and staffing levels made possible by annual budgets provided by state legislatures to their sister institutions. Tribes that must rely on often unpredictable federal funding and grantsmanship are at a distinct disadvantage in planning for further development of their campuses, including library facilities and services.

It is evident that tribal college administrators are determined to overcome the circumstances that impede their institutions' progress, and are succeeding in their efforts to provide postsecondary educational opportunities for their own people. Also clear to the authors of this study is the fact that these colleges will continue to shape their own paradigm for survival, melding classic educational programs with tribal culture.

This study provided some preliminary data describing the tribally controlled college libraries. As with most studies, however, it raised almost as many questions as it answered. Questions yet to be explored include, but are not limited to:

- How many of the graduate-degreeholding directors have degrees from ALA-accredited programs? Of those who do not, what degrees do they hold, and where have they obtained library and information studies courses? Can the trend toward offering distance education programs by many library schools positively affect library personnel likely to be employed in these colleges?

- Who serves on the advisory committees/library boards of these libraries? Given the broad-based academic missions of the colleges, it is expected that membership is more inclusive than faculty and students. What role do tribal members or administrators play in library operations?

- Other than Indian and tribal materials, are there other areas of collection strengths in these academic libraries? How are newer technologies being utilized in collection development?

- How much interest do these libraries have in performing archival, preser- vation, and records management functions? And, if the interest is there, how might implementation of these functions be facilitated? What staffing and training needs are unmet in these areas?

- Given that there is evidence of working relationships already in existence between some state libraries and the tribal college libraries, what roles are the state libraries filling for these libraries?

- What effect will changes in federal legislation have on tribal access to monies formerly earmarked for them through the LSCA, Title IV? In the future, it is likely that any such money will be directed to state libraries, and tribes will have to compete with other public libraries for funds. In the past, tribes have not fared well in similar situations, and are viewed as a "federal responsibility" by some state library administrators, which absolves any perception of responsibility for serving tribal libraries.

- What impact will the the new landgrant status have on the development of library resources and services? Will this status result in a more stable funding base?

Obviously, many questions have yet to be answered. However, the data cannot be divorced from the contextual realities of tribal people designing their own institutions to address their educational needs. This vision is best summarized in the Cheyenne River Community College catalog, which states: "The college truly believes that the reservation is the campus...."18 This statement reflects a holistic philosophy of integration deeply entrenched within Native American communities. Not only are they perpetuating cherished legacies, they are fostering an intellectual climate reflective of Indian values and providing opportunities for tribal members to acquire skills necessary for ensuring the viability of Native American people in the twenty-first century. As a vital part of both their college and tribal communities, tribal college libraries are a paradigm for educational and cultural survival. 


\section{Notes}

1. American Indian Higher Education Consortium brochure (Washington, D.C.: American Indian Higher Education Consortium, 1995).

2. Scott Jaschik, "President Clinton Signs Law Making 29 Tribal Colleges Land-Grant Institutions," Chronicle of Higher Education (Nov. 9, 1994): A32.

3. NACIE Newsletter 11 (Dec. 1994): 4.

4. Ibid.

5. Bay Mills Community College Catalog (Brimley, Mich.: Bay Mills Community College, 1994 96), 2.

6. Fort Belknap College Catalog (Harlem, Mont.: Fort Belknap College, 1994-95), 4.

7. Fort Berthold Community College Catalog (New Town, N.D.: Fort Berthold Community College, 1994-95), 7.

8. James F. Hill, Tribal Colleges: A Success Story, 1994, ERIC doc. no. ED 370-623, 2.

9. Lionel R. Bordeaux, "This Is the Way It Must Be," Tribal College 2 (fall 1990): 8; quoted in James F. Hill, Tribal Colleges: A Success Story, 2.

10. Wayne Stein, "Tribal Colleges: A Success Story," New Directions for Community Colleges 20 (winter 1992): 91.

11. Hill, Tribal Colleges, 6.

12. AIHEC brochure.

13. Federal Register 40, no. 172 (Sept. 4, 1995): 40983.

14. Senate, Report 103-104: Land Grant Status for Certain Indian Colleges (Nov. 9, 1995), 3.

15. Senate Committee on Indian Affairs, Equity in Educational Land Grand Status Act of 1993, 103rd Cong., 1st session, Nov. 18, 1993. S1345 Hearing, 73.

16. Hill, Tribal Colleges, 13.

17. Montana Indian Tribal Libraries Group Newsletter 1 (summer 1994): 7.

18. Cheyenne River Community College Catalog (Eagle Butte, S.D.: Cheyenne River Community College, 1993-95): 4.

\section{Join ACRL in Nashville!}

\section{April 11-14, 1997}

\section{Be a presenter}

Presenters needed for poster sessions and roundtable discussions. Choose from these five theme tracks: partnerships and competition; changing work, roles, and organizations; social responsibility, equity, and diversity; funding; learning.

Get the complete "Call for Participation" in the January 1996 CERL News or at http://www.ala.org/acrl.html.

\section{Share ideas}

Stimulating discussions on topics of critical importance to the future of academic librarianship.

\section{Attend preconferences}

Practical workshops for creating skills to "choose your future" on topics such as fundraising, buildings, and electronic collections; case studies on how librar-

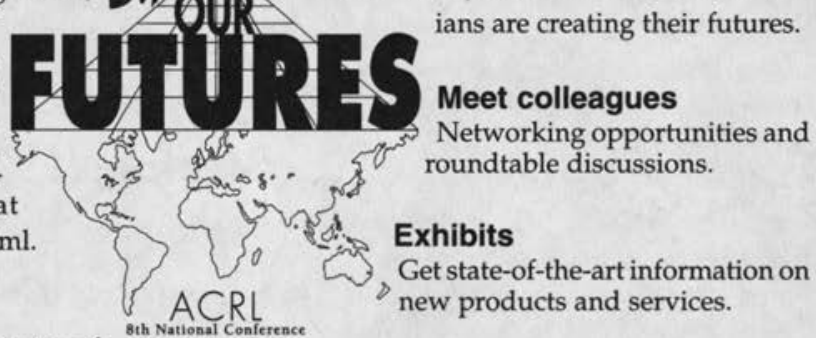

\section{Local tours}

See the Grand Ole Opry-and more.

\section{Keep up with the latest on ACRL's conference plans!}

\section{Participate in the dialogue of the future of academic librarians via the Web. \\ Point your Web browser to: http://www.ala.org/acrl.html.}

Registration materials will be mailed to ACRL members in September 1996. To be added to the mailing list contact Darlena Davis at (800) 545-2433, ext. 2519 or ddavis@ala.org 


\section{Perception Reality}

\section{Perception}

Any vendor can provide adequate coverage of English language titles.

\section{Perception}

All approval vendors provide the same level of bibliographic expertise.

\section{Perception}

Traditional bibliographic resources are sufficient to manage a library's needs.

\section{Reality}

Blackwell's unified US \& UK buying provides comprehensive approval coverage of English language scholarly publications.

\section{Reality}

Blackwell's professional bibliographers deliver a consistently higher level of bibliographic control for the entire range of English language titles.

\section{Reality}

Blackwell pioneered coordinated US \& UK Internet/Web accessible tools providing better resources to meet the needs of modern libraries.

\section{Blackwell's Preferred Edition} provides the REALITY of complete English language approval services.

Second in a series from BLACKWELL 